T.V. Bgasheva, E.A. Ahmetshin, E.V. Zharikov

D. Mendeleyev University of Chemical Technology of Russia, Department of chemistry and technology of crystals, 125480, Geroev Panfilovtsev str. 20/1, Moscow, Russia

T.B@live.ru

\title{
HEAT TREATMENT ENHANCEMENT OF NATURAL ORANGE-RED SAPPHIRES
}

\begin{abstract}
Certain variety of Madagascar color sapphires (fancy sapphires) has orange-red color, which shades don't let to consider them as the rubies. Heat treatment experiments in reducing atmosphere were carried out on such sapphires for the purpose of improving their color characteristics. Chromium (III), iron (II and III), titanium (IV) chromophore impurities in natural corundum and chromophore centers with their participitation are considered. A special attention is paid to spectral characteristics of chromophore centers. Behavior of the chromophore centers under heat treatment and their influence on the color of fancy sapphires are studied. Color modification mechanism was proposed on the basis of microprobe and spectral analyses data. The proposed enhancement technique allows to improve color characteristics of fancy sapphires.
\end{abstract}

Key words: corundum, fancy sapphires, enhancement, heat treatment, chromophore center

\section{INTRODUCTION}

Improving quality of gemstones and especially their color by heat treatment is widely used in the enhancement of rubies and sapphires. Production of high-quality rubies declines everywhere and these gems are still much in demand, but at the same time there are mines where so-called color sapphires and poor quality rubies are found. Corundum varieties which do not have the true red ruby or blue sapphire color are termed color sapphires, color corundums, fancy colored sapphires or fancy sapphires. Undesirable color tints in red corundum can significantly bring down its value since such color won't allow to classify these stones as rubies.

Madagascar is one of the main suppliers of color sapphires. Most part of the Madagascan sapphires are orange-red and red sapphires with brownish-orange tint. These "unwanted" tints considerably affect on the quality characteristics of sapphires. It is this kind of fancy sapphires that the object of study in this paper.

Achieving of ruby color in such sapphires will significantly improve their quality characteristics and therefore value. The most acceptable method of enhancing is heat treatment considering advantages of this method. Also there are premises on which the undesirable tints in corundums are caused by the impurity of iron ions and can be removed after heat treatment in reducing conditions. 


\section{Chromofore impurities in corundum}

Corundum $\alpha-\mathrm{Al}_{2} \mathrm{O}_{3}$ has trigonal crystal symmetry. The crystal structure of corundum is the close hexagonal packing of anions $\mathrm{O}^{2-}$, in which two-thirds of the octahedral sites are occupied with the aluminum ions $\mathrm{Al}^{3+}$. Coloration of corundum is mainly caused by $3 \mathrm{~d}$-ions (ions of transition elements $\mathrm{Ti}, \mathrm{V}, \mathrm{Mn}, \mathrm{Fe}, \mathrm{Ni}$, etc., these elements have unpaired electrons on external orbitals) which replace the $\mathrm{Al}^{3+}$ ions in the structure during the crystallization. It is possible because the size of the $3 \mathrm{~d}$-transition element ions is close to the size of the ions $\mathrm{Al}^{3+}$. The available data on the parameters of crystal field of $3 \mathrm{~d}$-transition elements substituting $\mathrm{Al}^{3+}$ ions in the lattice of corundum suggest that the first few excited states of all elements lie in the visible region. All 3d-elements, if they are present in corundum, will participate in coloration mechanisms. Mechanisms may cause the absorption band with intensity from weak to strong, electronic transitions in these bands lead to a variety of sapphire colors ranging from purple to red.

The color is a superposition of light waves that are not absorbed by mineral when passing through a mineral or reflecting from its surface, therefore one or another optically active centers in the mineral which selectively absorb light of certain wavelengths will be responsible for the coloration. Transition d-elements present in corundum as isomorphic impurities are these centers. These elements are often referred to as chromophore.

Chromophore ions can be both isolated and bounded and can occupy different structural positions relatively to each other. Chromophore effect of the presence of transition element ions strongly depends on the structural component. Thus, impurity ions can occupy either isolated from each other octahedral sites in the lattice or occupy the neighboring octahedral sites. In this case intensive electron exchange interactions between the ions of transition metals accompanied by the formation of additional energy levels of these ions and by the appearance of additional absorption bands in the spectra can arise. In the mineralogical literature these bands are referred to as the absorption band of charge transfer metal $\rightarrow$ metal or absorption bands of exchange-coupled pairs. These bands are tenfold to a hundredfold more intensive than absorption bands of the spin-allowed $\mathrm{d}-\mathrm{d}$ absorption bands as they corresponds to the d-d transitions with a considerable touch of electronic states. Not infrequently when isolated impurities themselves do not contribute considerably to the overall color of the mineral but if they are simultaneously present in neighboring positions of the lattice it causes visible changes in mineral coloration.

\section{The influence of chromophore centers on the color of fancy sapphires}

According to the microprobe analysis data the main impurities forming color centers in the given color sapphires are: chromium $\mathrm{Cr}$ (III), iron Fe (II and III) and titanium Ti (IV). Chromium (III) and iron (II and III) present as ions, titanium (IV) can present both as ions and solid phase as inclusions of rutile $\mathrm{TiO}_{2}$. Depending on the concentration and quantity ratios between chromophore impurities the color of corundum has different tints and intensity.

There are intense broad absorption bands in the visible region of optical spectra due to the spin allowed electronic transitions in the chromium ions $\mathrm{Cr}^{3+}$ [4], that give the red color. Corundum containing a certain amount of $\mathrm{Cr}^{3+}$ in the absence of other chromophore impurities has a ruby red color.

Chromophore centers with pairs of $\mathrm{Fe}^{3+}$ and $\mathrm{Fe}^{3+}-\mathrm{Fe}^{3+}$ may cause yellow, brownish and yellowish tints which are undesirable in red stones. Color of iron-containing corundum may 
also be caused by the combined effect of intensive charge-transfer band $\mathrm{Fe}^{3+} \rightarrow \mathrm{O}^{2-}$ located in the UV region with its long-wavelength "shoulder" laying in the visible spectrum region and by absorption bands in the visible spectrum, most of which are due to d-d transitions in $\mathrm{Fe}^{3+}$ ions. The absorption bands of $\mathrm{Fe}^{3+}-\mathrm{Fe}^{3+}$ appear in the same spectral range as bands of isolated ions $\mathrm{Fe}^{3+}$, but the former ones have a much greater intensity and a clearly defined structure owing to the levels splitting by exchange interaction [3].

In some cases yellow color in natural corundum might be conditioned not by impurity but radiation color centers - oxygen hole centers $\mathrm{O}^{-}$. Hole centers are often formed in nature under the influence of ionizing radiation from the surrounding rocks. The absorption bands of $\mathrm{O}^{-}$ center are located in the 220-330 nm region but its long-wavelength "tail" can fall into the visible region of the spectrum causing a yellowish and brownish tints in color [2].

The absorption bands associated with $\mathrm{Fe}^{2+}$ and $\mathrm{Fe}^{2+}-\mathrm{Fe}^{3+}$ lie outside the visible range so only the "tails" of the absorption bands have weak influence on the sapphire color, it gives to crystals greenish and bluish colors. Some authors also reported about absorption band of these centers in the visible spectrum $[3,5,6]$, but there is no definite opinion about this band $[7,8]$. Isolated impurity ions $\mathrm{Ti}^{4+}$ do not have any absorption bands in the visible region. If the adjacent positions in lattice are occupied by both $\mathrm{Fe}^{2+}$ and $\mathrm{Ti}^{4+}$ then an absorption band in the visible spectrum due to intervalent charge transfer $\mathrm{Fe}^{2+} \rightarrow \mathrm{Ti}^{4+}$ appears. Titanium ions are bound in pairs with iron ions thereby forming so-called "biparticles" $(\mathrm{Fe}, \mathrm{Ti})^{6+}$. Chromophore centers $\mathrm{Fe}^{2+}-\mathrm{Ti}^{4+}$ give to sapphires blue color [9]. It should be noted that if these impurities' content even of hundredths parts of a percent then blue color appears. For example, aluminum oxide containing $\mathrm{Fe}-0,071$ wt. \% and Ti - 0,012 wt. \% has a dark blue color [10].

The number of studies where blue color of sapphire is attributed to the combined effect of iron and titanium ions $\mathrm{Fe}^{2+}-\mathrm{Ti}^{4+}$ is quite large $[3,7,10,11,12,13]$. However, in a number of papers it is considered that the blue color is caused by absorption of centers containing only $\mathrm{Fe}^{2+}$ and $\mathrm{Fe}^{3+}$, the ratio $\mathrm{Fe}^{2+} / \mathrm{Fe}^{3+}$ being of certain values $[5,6,14]$. In this case titanium impurity if present in stone bears no direct relation to the blue color. Attribution of the absorption bands is complicated by the fact that both intervalent transfers $\mathrm{Fe}^{2+}-\mathrm{Fe}^{3+}$ and $\mathrm{Fe}^{2+}-$ $\mathrm{Ti}^{4+}$ exhibit absorption near the red end of visible spectrum. Comparative study of optical absorption spectra of sapphire given in [3] shows that blue color of sapphire depending on the "typomorphic" features of their deposits can be caused by both $\mathrm{Fe}^{2+}-\mathrm{Ti}^{4+}$ centers and $\mathrm{Fe}^{2+}-\mathrm{Fe}^{3+}$ centers or by their combination. In Madagascar sapphires the predominant or even the only reason of the blue color is the $\mathrm{Fe}^{2+}-\mathrm{Ti}^{4+}$ chromophore centers $[15,16]$. Therefore in our article we accept the position about chromophore effect of $\mathrm{Fe}^{2+}-\mathrm{Ti}^{4+}$ pairs.

Besides the above mentioned chromophore impurities some quantities of $\mathrm{V}, \mathrm{Ti}, \mathrm{Mn}, \mathrm{Mg}$ and other elements can be responsible for tints in sapphire colors. Since there are only trace amounts of these impurities in given sapphires their contribution to the coloration of stone is negligible.

\section{SAMPLES AND METHOD}

\section{Characterization of samples}

The investigated color sapphires are presented as 12 groups of colors from yellow to red with different hues and saturations: color hues are oY, O, rO, and oR. Here and below the notation of colors by GIA color grading system GemSet ${ }^{\circledR}$ is used. Sample size - from 3 to $5 \mathrm{~mm}$. According to the microprobe analysis the main impurities are chromium, iron and titanium. In 
the untreated samples concentrations are: $\mathrm{Cr}_{2} \mathrm{O}_{3}-0.04-0.64$ wt. \%, $\mathrm{Fe}_{2} \mathrm{O}_{3}-0.50-0.96$ wt. \%, $\mathrm{TiO}_{2}$ - up to 0.04 wt. \%. Data on the concentrations of impurities $\mathrm{Cr}_{2} \mathrm{O}_{3}$ and $\mathrm{Fe}_{2} \mathrm{O}_{3}$ in the investigated sapphires are shown in Fig. 1. These impurities in various combinations give to corundum variety of observed colors.

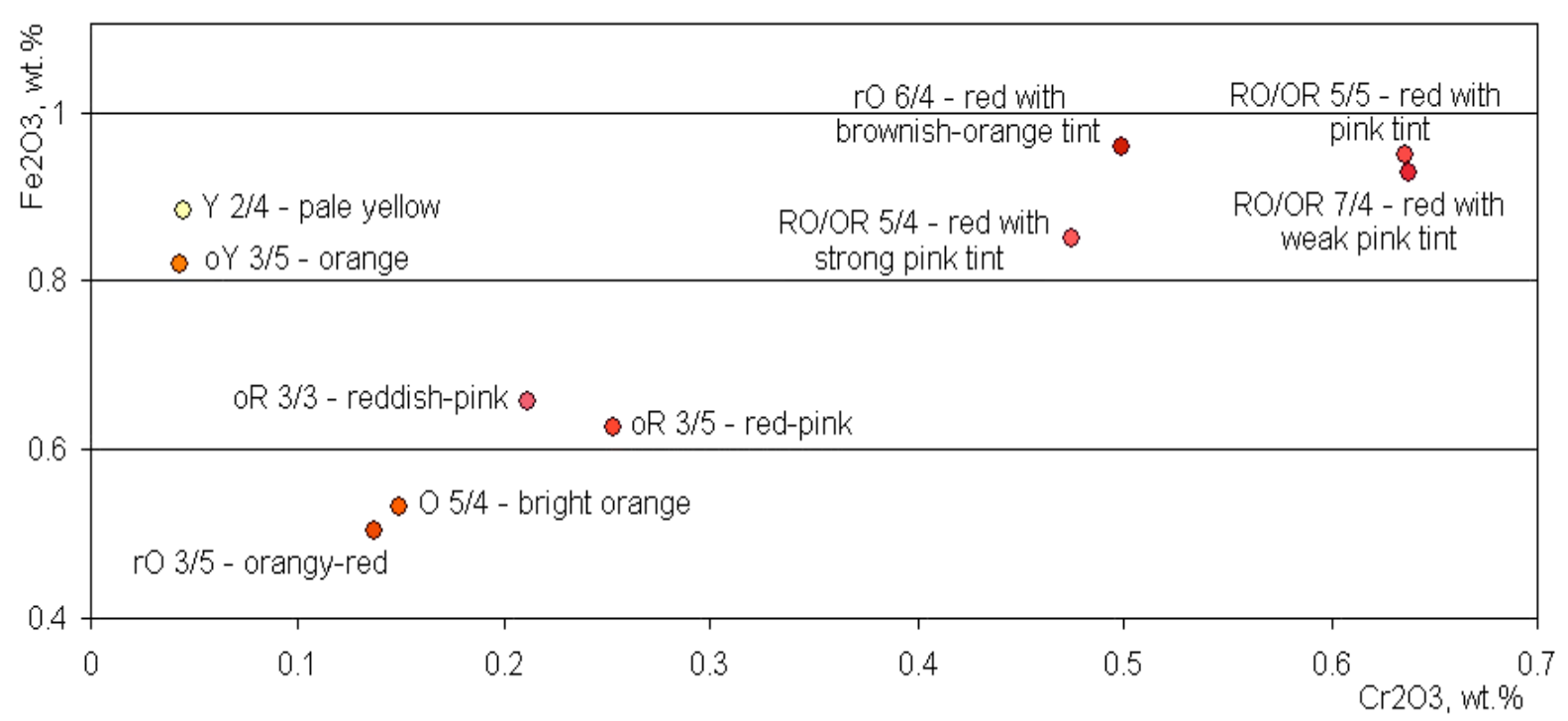

Fig. 1. Concentrations of $\mathrm{Cr} 2 \mathrm{O} 3$ and $\mathrm{Fe} 2 \mathrm{O} 3$ (wt\%) in the investigated natural color sapphires of Madagascar (untreated samples)

Concerned sapphires contain chromophore centers which absorption bands in the visible spectrum are overlapped by the more intensive absorption bands of other impurity color centers. The samples contain sufficient amount of $\mathrm{Cr}^{3+}$ but some of these ions is in "masked" state and does not become apparent in full in the absorption spectra mainly because of the "overlapping action" of the chromophore centers containing $\mathrm{Fe}^{3+}$. Data on the elemental composition of samples with color from pale yellow to reddish-pink and their absorption spectra [17] confirm that.

Common for the initial samples absorption peaks of following chromophore centers have been identified on the optical absorption spectra of bright orange $\mathrm{O} 5 / 4$, orangy-red $\mathrm{rO} 3 / 5$, orange oY $3 / 5$ and the red-orange $\mathrm{rO} 4 / 5$ sapphires before heat treatment (absorption bands attribution by $[3,4,18]): \mathrm{Cr}^{3+}(540-560 \mathrm{~nm}), \mathrm{Fe}^{3+}-\mathrm{Fe}^{3+}(450 \mathrm{~nm})$ and $\mathrm{Fe}^{3+} / \mathrm{Fe}^{3+}-\mathrm{Fe}^{3+}(700 \mathrm{~nm})$. The absorption band of $\mathrm{Cr}^{3+}$ is distorted at $540-560 \mathrm{~nm}$ because of the intensive absorption of $\mathrm{Fe}^{3+}-\mathrm{Fe}^{3+}$ at $450 \mathrm{~nm}$. Some samples also exhibit absorption bands of $\mathrm{Fe}^{3+}(388 \mathrm{~nm}), \mathrm{Cr}^{3+}$ $(400-410 \mathrm{~nm}), \mathrm{Fe}^{3+}-\mathrm{Fe}^{3+}(377 \mathrm{~nm})$ and $\mathrm{Fe}^{3+} / \mathrm{Fe}^{3+}-\mathrm{Fe}^{3+}(540 \mathrm{~nm})$. Determination whether there are any hole centers $\mathrm{O}^{-}$in the initial corundum is difficult since the long-wavelength "tail" of their absorption can not be defined explicitly on the spectra. Fig. 2 shows examples of spectra of the initial untreated color sapphires. 


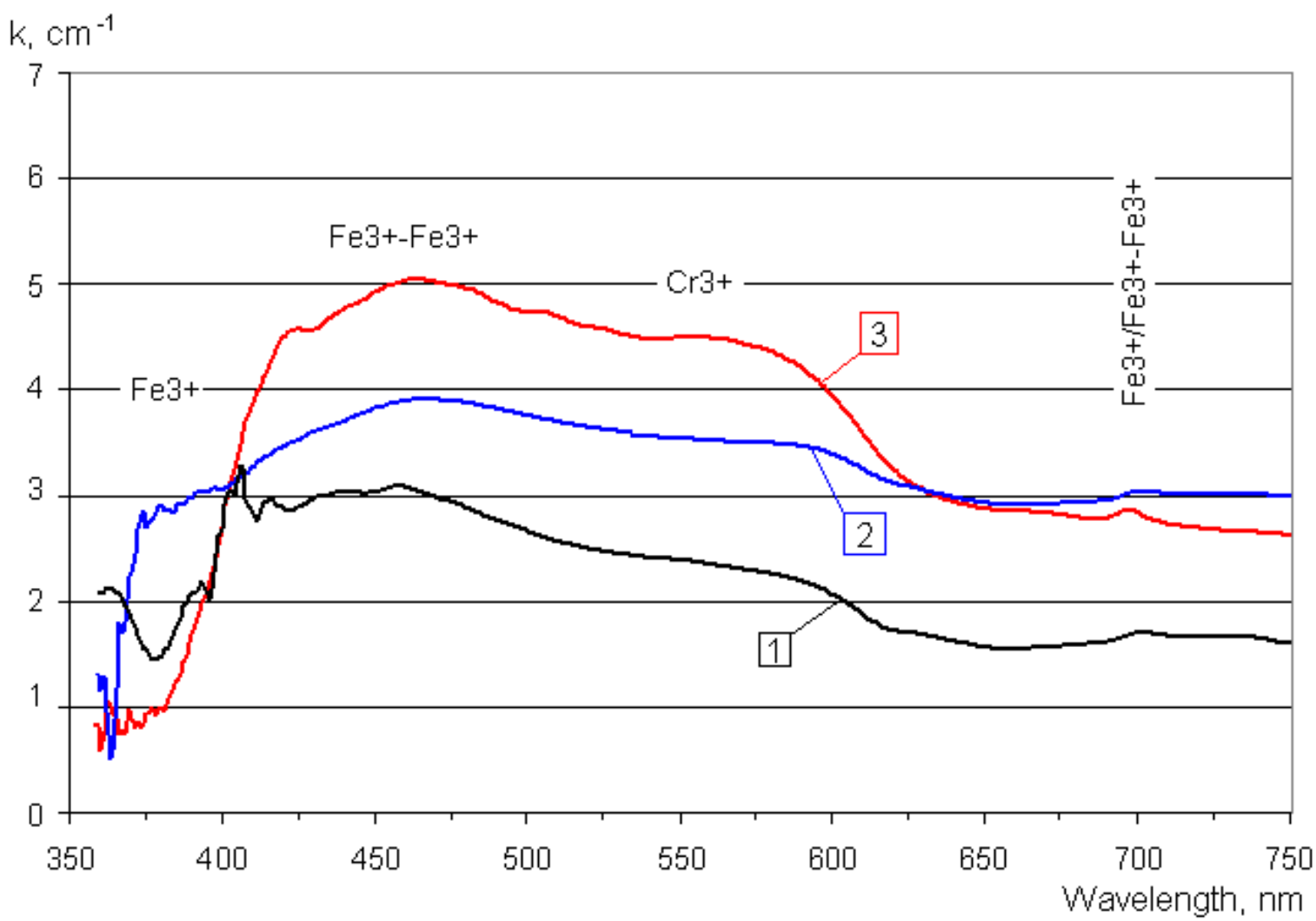

Fig. 2. Optical absorption spectra of some fancy sapphires before heat treatment: 1 - O 5/4, bright orange, 2, 3 - rO 4/5, red-orange

\section{Method and its explanation}

In order to remove undesirable tones in the color of orange-red sapphires it is necessary to destruct chromophore centers containing $\mathrm{Fe}^{3+}$ and $\mathrm{O}^{-}$. It is known that the hole center $\mathrm{O}^{-}$is unstable and when getting of sufficient light or heat energy, it captures an electron and turns into $\mathrm{O}^{2-}$, and color center is destructed [19]. According to our data [20] heat treatment at 200$300^{\circ} \mathrm{C}$ is enough to destruct the hole color centers in sapphires and remove coloration caused by them. Impurity ions can not be completely removed during the heat treatment, so the problem comes to decreasing the amount of these centers. It is possible to decrease the concentration of $\mathrm{Fe}^{3+}$ by reducing it to other valent state $-\mathrm{Fe}^{2+}$. Chromophore centers with $\mathrm{Fe}^{2+}\left(\mathrm{Fe}^{2+}, \mathrm{Fe}^{2+}-\mathrm{Fe}^{3+}\right.$ and $\left.\mathrm{Fe}^{2+}-\mathrm{Ti}^{4+}\right)$ cause greenish, bluish and blue colors of different intensities in corundum.

Natural color sapphires usually contain some amount of titanium as fine rutile "needle" microcrystalls $\mathrm{TiO}_{2}$. Under heat treatment it can dissolve and passing into the state of $\mathrm{Ti}^{4+}$ and combining with iron ions can form $\mathrm{Fe}^{2+}-\mathrm{Ti}^{4+}$ chromophore centers. Chromophore pairs $\mathrm{Fe}^{2+}-$ $\mathrm{Ti}^{4+}$ can have a significant influence on the coloration of corundum after heat treatment due to the broad absorption band in the visible spectrum $(565-700 \mathrm{~nm})[11,12]$. When concentrations of this chromophore center are at the low levels then absorption will have no significant effect on the color of heat treated sapphires.

Changing of valent state of iron impurity $\mathrm{Fe}^{3+} \rightarrow \mathrm{Fe}^{2+}$ under heat treatment can be carried out upon reducing conditions. The temperature of the heat treatment must be at least $1000^{\circ} \mathrm{C}$ due to the impossibility of active redox processes in sapphires below this temperature [21]. 
Thus, the problem comes to finding the optimal conditions under which a sufficient number of $\mathrm{Fe}^{3+}$ ions will be reduced to $\mathrm{Fe}^{2+}$, and at the same time chromophore center $\mathrm{Fe}^{2+}-\mathrm{Ti}^{4+}$ being formed in small amounts. Also, heat treatment should not cause the formation of new phases within the samples. Achieving a low concentration of $\mathrm{Fe}^{2+}-\mathrm{Ti}^{4+}$ by reducing the amount of $\mathrm{Fe}^{2+}$ contradicts problem of decreasing the concentration of $\mathrm{Fe}^{3+}$. So it is necessary to limit the formation of additional amount of $\mathrm{Ti}^{4+}$ ions from the solid phase of "needles" $\mathrm{TiO}_{2}$, because the amount of titanium ions dissolved initially in the crystal and which could potentially participate in pairs $\mathrm{Fe}^{2+}-\mathrm{Ti}^{4+}$ can not be changed. If the experiments show a significant effect of $\mathrm{Fe}^{2+}-\mathrm{Ti}^{4+}$ chromophore center on the color of sapphires then additional formation of $\mathrm{Ti}^{4+}$ can be limited by the prevention of dissolving of the rutile microcrystals during heat treatment. In this case experiments should be carried out at temperatures lower than the rutile melting point, i.e. at temperatures below $1600^{\circ} \mathrm{C}$. On the other hand, the efficiency of reducing of iron ions and the corresponding reaction rate depends on temperature. It is known that increasing temperature increases reaction. Corundum concerned do not contain such an amount of impurities of titanium and iron, which can significantly affect the result of heat treatment, so for our experiments temperature range $1100-1800^{\circ} \mathrm{C}$ was originally chosen.

Some remarks should be done about the behavior of other impurities during the heat treatment. It is logical to assume the existence of $\mathrm{Ti}^{3+}$ impurities in the untreated sapphires. Indeed, when titanium is the only impurity in sapphire then there is the absorption band in the ultraviolet region [4, 22] and a broad band at $500 \mathrm{~nm}$ in the visible region $[4,18,23]$. But if there is tenths of a percent of impurities $\mathrm{Fe}^{3+}$ absorption band of $\mathrm{Ti}^{3+}$ in the visible region is overlapped by much more intensive bands of centers with $\mathrm{Fe}^{3+}[18]$, which occurs in natural sapphires. Perhaps for this reason authors of [12] report that have not yet been observed any absorption bands of $\mathrm{Ti}^{3+}$ in a natural or in natural but heat treated sapphire. In [16] a lack of absorption of $\mathrm{Ti}^{3+}$ in natural corundum also noted.

In the $\mathrm{Cr}-\mathrm{Ti}-\mathrm{Fe}$ series oxidation power increases, so if there is impurity of $\mathrm{Fe}^{3+}$, which is more effective as an electron acceptor than $\mathrm{Ti}^{3+}$ then the conditions for the formation of $\mathrm{Ti}^{4+}$ are created, $\mathrm{Fe}^{2+}$ being produced (iron ion can gain an electron whereas titanium ion can lose one). Therefore, in sapphire when the concentration of electron-acceptor impurities exceeds the concentration of dissolved titanium ions then $\mathrm{Ti}^{3+}$ would not exist in any significant quantities [12]. In our samples the content of iron ions is much larger than the titanium ions content. Investigated samples do not contain visible inclusions of rutile, so the correction for the amount of the titanium which was not analyzed by the microprobe analysis, is negligible. Thus, all titanium ions will be bound in "biparticles".

Valence change of titanium and chromium ions after reducing heat treatment cannot be completely excluded. Probable states after reducing treatment of ion $\mathrm{Cr}^{3+}-$ is $\mathrm{Cr}^{2+}$, of ion $\mathrm{Ti}^{4+}$ - is $\mathrm{Ti}^{3+}$ and $\mathrm{Ti}^{2+}$. The absorption bands associated with the reduced forms of titanium lie outside the visible range in the region 200-320 $\mathrm{nm}$. The bands of $\mathrm{Cr}^{2+}(400,550 \mathrm{~nm})$ lie in the visible range almost matching with the bands of $\mathrm{Cr}^{3+}$. It is also noted that the color caused by these chromium centers is removed after heating at $300^{\circ} \mathrm{C}[4,22] . \mathrm{In}[24]$ it is reported that the reducing conditions of heat treatment alter the oxidation state of iron, but it seems to have no effect on the oxidation state of titanium. Thus, if there is any reducing of chromium and titanium impurities then their absorption bands do not affect on the final observed color. 


\section{Experiment}

For heat treatment of color sapphires the original high-temperature electric induction furnace was used. The experimental setup is shown in Fig. 3. Depending on the material and desired color of sapphire after heat treatment different temperature regimes were used. Additionally a special gas atmosphere for heat treatment was created by means of selected agents with different redox power.

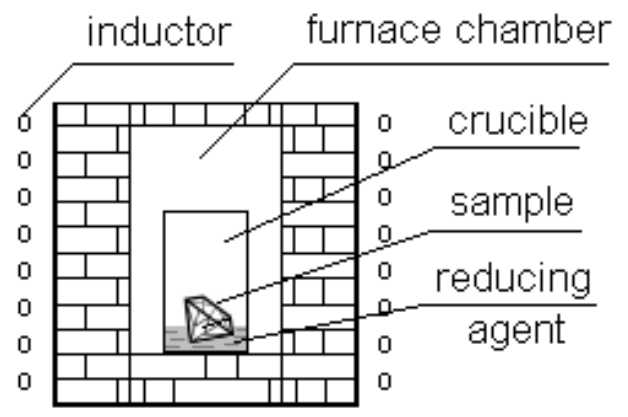

Fig. 3. Simplified scheme of experimental setup for heat treatment of color sapphires

X-ray microprobe analysis was performed on electron probe x-ray analyser Camebax SX50 $(15 \mathrm{kV}, 30 \mathrm{~ns})$. Scanning electron microscopy was performed on scanning electron microscope BS-340 TESLA (30 kV, Cu). Optical absorption spectra were obtained using spectrophotometer SF-56 with a special add-on device. The samples are faceted stones. Samples were mounted so its top flat face were perpendicular to the spectrophotometer beam. Series of heat treatment of orange-red sapphires were carried out in oxidizing and reducing atmospheres at different temperatures in the range $1100-1800^{\circ} \mathrm{C}$ and with holding time at working temperatures varying from 30 to $180 \mathrm{~min}$. For obtaining reducing atmosphere the reducing agent containing amorphous carbon was used, which was placed in a crucible with the samples. The crucible was placed then in the furnace chamber and heat treatment program was launched on. End of the heating program was followed by natural cooling down of furnace till room temperature. Oxidizing heat treatment was carried out in air atmosphere.

\section{RESULTS}

Color of the samples and optical absorption spectra were taken before and after experiments. Fig. 4 schematically shows the results of heat treatment of color sapphires in reducing atmosphere for ranges $1100-1200^{\circ} \mathrm{C}$ and $1400-1700^{\circ} \mathrm{C}$. The arrows in the figure indicate the direction of color change in the sample, the starting point of the arrow indicates the color of the initial sample and the end point of the arrow indicates the obtained color. Photo 1 represents samples before and after reducing heat treatment at different temperatures in the range $1100-1700^{\circ} \mathrm{C}$. Photo 2 shows another sample after reducing heat treatment in the range $1400-1700^{\circ} \mathrm{C}$. 


\begin{tabular}{|c|c|c|c|}
\hline \multicolumn{2}{|l|}{ Temperature range } & \multicolumn{2}{|c|}{$1400-1700^{\circ} \mathrm{C}$} \\
\hline Color & after & \multicolumn{2}{|c|}{ before after } \\
\hline \multicolumn{4}{|l|}{ Y $2 / 4$ - pale yellow } \\
\hline \multicolumn{4}{|l|}{ oy $2 / 3$ - pale yellow-orange } \\
\hline \multicolumn{4}{|l|}{ oY $2 / 4$ - vellow-orange with brown tint } \\
\hline \multicolumn{4}{|l|}{ oY $3 / 4$ - light orange with brown tint } \\
\hline \multicolumn{4}{|l|}{ oY $3 / 5$ - orange } \\
\hline \multicolumn{4}{|l|}{$05 / 4$ - bright orange } \\
\hline \multicolumn{4}{|l|}{ ro $3 / 5$ - orangy-red of } \\
\hline \multicolumn{4}{|c|}{ ro $4 / 3$ - pink-orange } \\
\hline \multicolumn{4}{|l|}{ ro $4 / 4$ - reddish-orange } \\
\hline \multicolumn{4}{|l|}{ ro 5/4 - orange-red with slightly pink tint } \\
\hline \multicolumn{4}{|l|}{ ro $4 / 5$ - red-orange } \\
\hline \multicolumn{4}{|l|}{ ro $5 / 5$ - orange-red } \\
\hline \multicolumn{4}{|l|}{ rO $6 / 4$ - red with brownish-orange tint } \\
\hline \multicolumn{4}{|l|}{ RO/OR $5 / 6$ - red with weak pink tint } \\
\hline \multicolumn{4}{|l|}{ RO/OR $5 / 5$ - red with pink tint } \\
\hline \multicolumn{4}{|l|}{$\mathrm{RO} / \mathrm{OR} 5 / 4$ - red with strong pink tint } \\
\hline \multicolumn{4}{|l|}{ RO/OR 7/4 - dark red with weak pink tint } \\
\hline \multicolumn{4}{|l|}{ RO/OR $7 / 3$ - dark red with pink tint } \\
\hline \multicolumn{4}{|l|}{ oR $3 / 2$ - pale reddish-pink } \\
\hline \multicolumn{4}{|l|}{ oR $3 / 3$ - reddish-pink } \\
\hline \multicolumn{4}{|l|}{ oR $3 / 5$ - red-pink } \\
\hline \multicolumn{4}{|l|}{ oR $6 / 4$ - pink-red } \\
\hline \multicolumn{4}{|l|}{ oR $6 / 2$ - pink-cherry } \\
\hline \multicolumn{4}{|l|}{ R $5 / 3$ - crimson-pink } \\
\hline \multicolumn{4}{|l|}{ R $6 / 4$ - crimson-red } \\
\hline \multicolumn{4}{|l|}{ stpR 8/3 - dark red with pink-cherry tint } \\
\hline \multicolumn{4}{|l|}{$\operatorname{stpR} 4 / 4$ - cherry-pink } \\
\hline \multicolumn{4}{|l|}{ stpR $4 / 3$ - cherry-pink } \\
\hline rP 5/3 - pink-violet & & & \\
\hline
\end{tabular}

Fig. 4. Results of heat treatment of color sapphires in reducing atmosphere
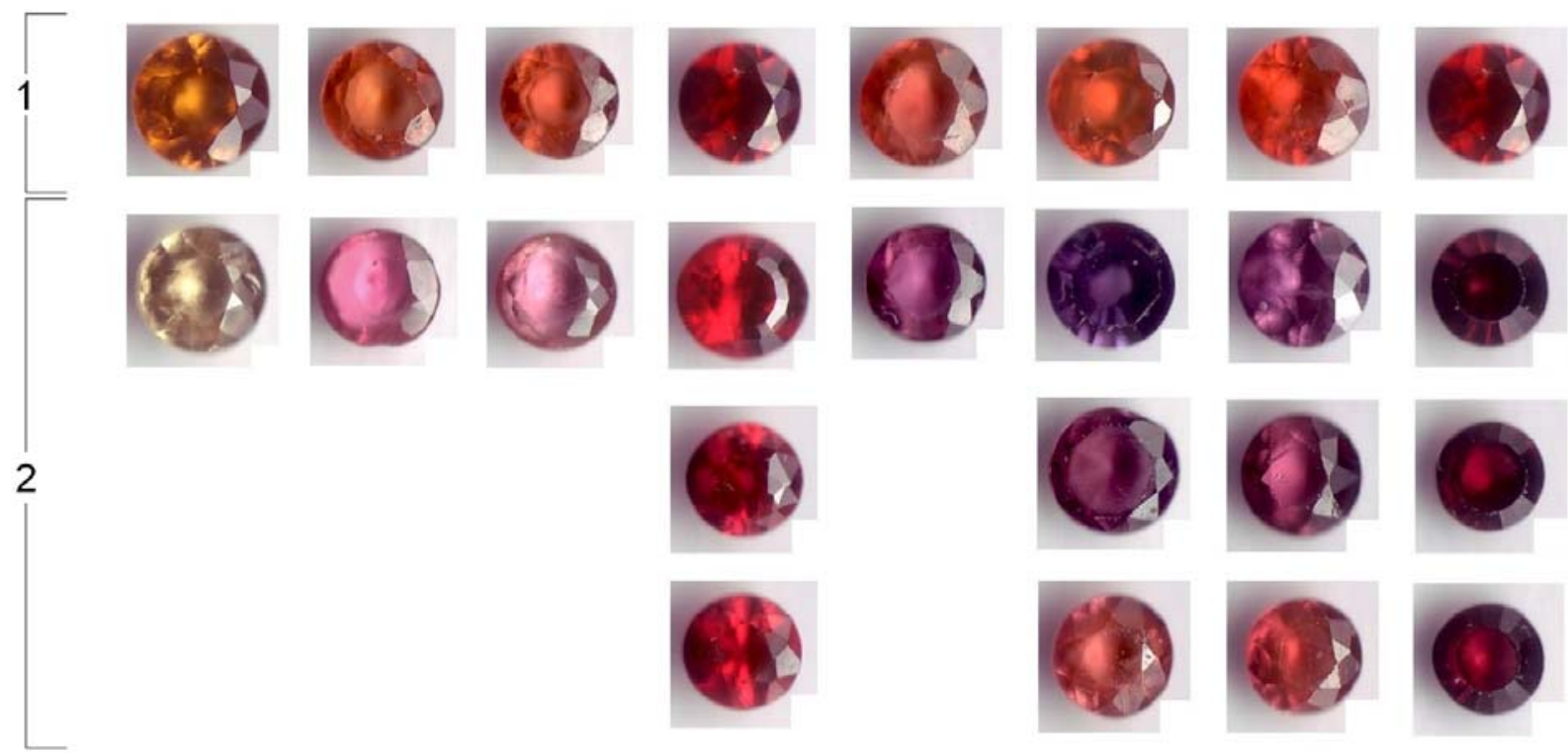

Photo 1. Samples of color sapphires before and after reducing heat treatment at $1100-1700^{\circ} \mathrm{C}(\mathrm{D}=2,5-3,0 \mathrm{~mm})$ : 1 - samples before heat treatment, 2 - samples after heat treatment. 

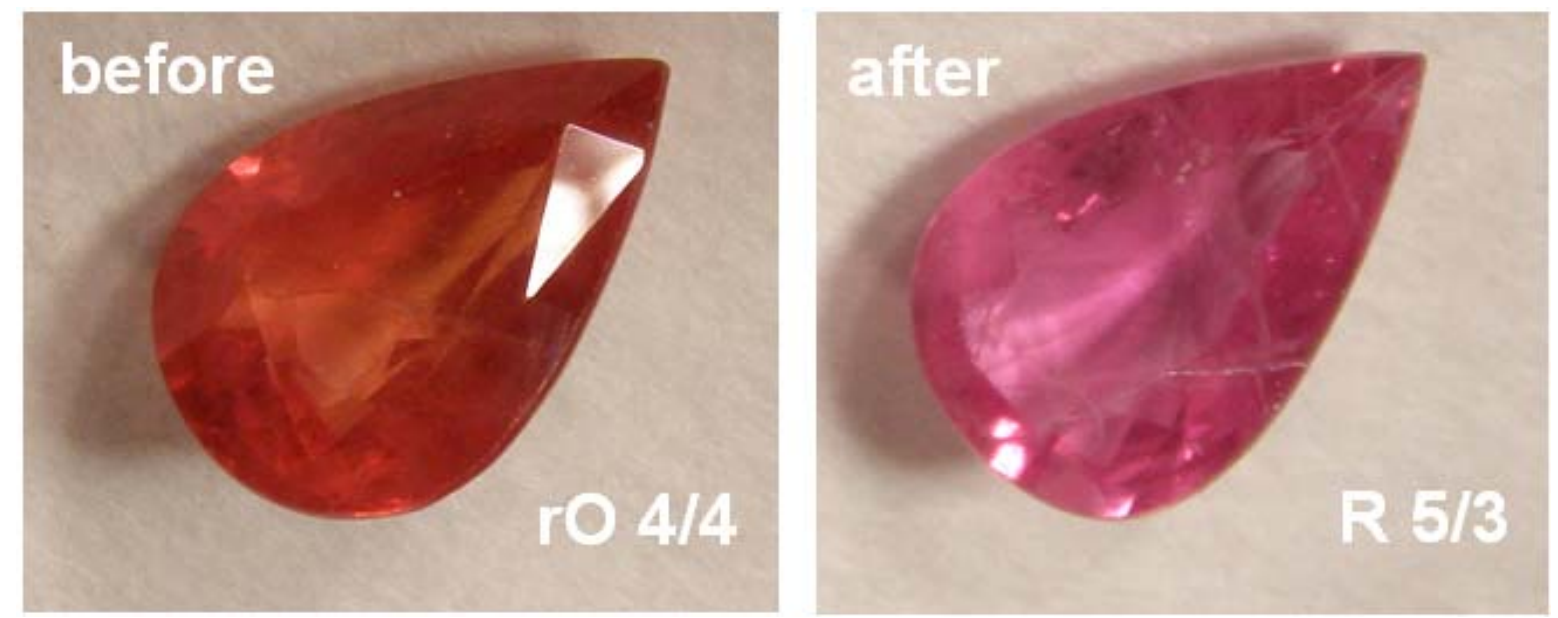

Photo 2. Sample of color sapphire before and after reducing heat treatment $(7 \times 4 \mathrm{~mm})$ : before heat treatment (left) - $\mathrm{rO} 4 / 4$, after heat treatment (right) - R 5/3.

Generalized experimental data showed that:

Oxidizing heat treatment at $1100-1200^{\circ} \mathrm{C}$ : sapphires of groups oR, RO/OR, rO, O, yO, oY do not undergo significant color changes. Depending on the experiment conditions these sapphires can become more saturated.

Reducing heat treatment at $1100-1200^{\circ} \mathrm{C}$ : orange-red sapphires of groups oR, RO/OR, $\mathrm{rO}, \mathrm{O}$ receive more pronounced red component in their color. The color of the yellow-orange sapphires $\mathrm{yO}, \mathrm{oY}$ can be shifted both into the red tones and into the yellow ones depending on the atmosphere's reducing potential and the impurity contents of the sample.

Reducing heat treatment at $1400-1700^{\circ} \mathrm{C}$ : depending on the atmosphere's reducing potential red-orange sapphires of group rO can either stay within their color group slightly changing the tone and saturation or get color in the range from orange-red $\mathrm{RO} / \mathrm{OR}$, oR through red $\mathrm{R}$ up to cherry stpR and violet $\mathrm{rP}$ tones. The absorption spectra of red-orange sapphire changed its color to cherry-pink color shown in Fig. 5. A complete loss of transparency occurs when heat treating at temperature about $1800^{\circ} \mathrm{C}$ : the sample gets gray-black color and therefore has no more gem value (Fig. 6). Detailed discussion of these figures is presented in the next chapter.

\section{DISCUSSION}

On the basis of data on the elemental composition of sapphires content ratios $\mathrm{Fe} / \mathrm{Cr}$ for samples of different colors were calculated, this made it possible to draw an interesting regularity of dependence of the sapphire color from the ratio $\mathrm{Fe} / \mathrm{Cr}$.

Table 1 presents data on the dependence of color of the samples from the ratio $\mathrm{Fe} / \mathrm{Cr}$. We can see when ratio $\mathrm{Fe} / \mathrm{Cr}$ increases then color changes in the line in a certain way: red $\rightarrow$ redpink $\rightarrow$ orange-red $\rightarrow$ orange $\rightarrow$ yellow. And every ratio $\mathrm{Fe} / \mathrm{Cr}$ is greater than 1, i.e. the concentration of iron ions is higher than concentration of chromium ions. 
Table 1. The dependence of color of the samples from the ratio $\mathrm{Fe} / \mathrm{Cr}$

\begin{tabular}{|l|l|l|}
\hline GIA GemSet ${ }^{(B)}$ & Color of the sample & $\mathrm{Fe} / \mathrm{Cr}$ \\
\hline $\mathrm{RO} / \mathrm{OR} 5 / 4$ & red with strong pink tint & 1,49 \\
\hline $\mathrm{RO} / \mathrm{OR} 5 / 5$ & red with pink tint & 1,53 \\
\hline $\mathrm{RO} / \mathrm{OR} 5 / 6$ & red with weak pink tint & 1,83 \\
\hline $\mathrm{rO} 6 / 4$ & red with brownish-orange tint & 1,97 \\
\hline oR 3/5 & red-pink & 2,53 \\
\hline oR 3/3 & reddish-pink & 3,18 \\
\hline $\mathrm{O} \mathrm{5/4}$ & bright orange & 3,65 \\
\hline rO 3/5 & orangy-red & 3,76 \\
\hline oY 3/5 & orange & 19,47 \\
\hline $\mathrm{Y} \mathrm{2/4}$ & pale yellow & 20,10 \\
\hline
\end{tabular}

As concerns the changes in spectral characteristics, on the optical absorption spectra of redpink oR 3/5, reddish-pink oR 3/3, pale yellow Y 2/4, pink-purple $\mathrm{rP} 5 / 3$ and the cherry-pink stpR 4/3 sapphires after heat treatment common for the treated samples absorption peaks of the following chromophore centers have been noted (absorption bands attribution by [3, 4, 18]): $\mathrm{Cr}^{3+}(540-560 \mathrm{~nm}), \mathrm{Fe}^{3+}-\mathrm{Fe}^{3+}(450 \mathrm{~nm})$ - except cherry-pink stpR 4/3 sample, $\mathrm{Fe}^{2+}-\mathrm{Ti}^{4+}$ $(565-700 \mathrm{~nm}), \mathrm{Fe}^{3+} / \mathrm{Fe}^{3+}-\mathrm{Fe}^{3+}(700 \mathrm{~nm})$, short-wavelength "tail" of the absorption band $\mathrm{Fe}^{2+}-$ $\mathrm{Fe}^{3+}(650-750 \mathrm{~nm})$ - except red-pink oR $3 / 5$ sample. On the spectra of all samples after heat treatment absorption band $\mathrm{Cr}^{3+}$ become much more distinctive, centers containing $\mathrm{Fe}^{2+}: \mathrm{Fe}^{2+}$ $\mathrm{Ti}^{4+}$ and $\mathrm{Fe}^{2+}-\mathrm{Fe}^{3+}$ appeared. Since the total iron content in the sample during heat treatment remains the same then appearance of $\mathrm{Fe}^{2+}$ ions means a decrease in the concentration of $\mathrm{Fe}^{3+}$, and, consequently, decrease in the intensity of the chromophore centers containing $\mathrm{Fe}^{3+}$. This decreasing of $\mathrm{Fe}^{3+}$ chromophore centers leads to a decrease in the intensity of the orange and yellow tints in the color of the samples. There is no effect of $\mathrm{Fe}^{2+}-\mathrm{Ti}^{4+}$ absorption on the color of the sample treated at $1150^{\circ} \mathrm{C}$ under reducing conditions due to insufficient amount of formed $\mathrm{Fe}^{2+}-\mathrm{Ti}^{4+}$ centers. One of the reasons causing violet and cherry-pink tones in the samples' color is a chromophore effect of pairs $\mathrm{Fe}^{2+}-\mathrm{Ti}^{4+}$ which occurs after heat treatment at $1500^{\circ} \mathrm{C}$ in reducing atmosphere.

The absorption spectra of the sapphire which had red-orange color $\mathrm{rO} 4 / 5$ before heat treatment and became cherry-pink stpR 4/3 after heat treatment are shown in Fig. 5. There are following absorption bands on the optical spectrum before heat treatment: $\mathrm{Cr}^{3+}(540-560 \mathrm{~nm})$, $\mathrm{Fe}^{3+}-\mathrm{Fe}^{3+}(377 \mathrm{~nm}, 450 \mathrm{~nm})$ and $\mathrm{Fe}^{3+} / \mathrm{Fe}^{3+}-\mathrm{Fe}^{3+}(700 \mathrm{~nm})$. The absorption peak of $\mathrm{Cr}^{3+}$ at $540-$ $560 \mathrm{~nm}$ is indistinct and it can be explained by the intensive absorption of $\mathrm{Fe}^{3+}-\mathrm{Fe}^{3+}$ at $450 \mathrm{~nm}$. There are following absorption bands on the optical spectrum after heat treatment: $\mathrm{Cr}^{3+}(400-$ $410 \mathrm{~nm}, 540-560 \mathrm{~nm}), \mathrm{Fe}^{2+}-\mathrm{Ti}^{4+}(565-700 \mathrm{~nm})$, short-wave "tail" of absorption of $\mathrm{Fe}^{2+}-\mathrm{Fe}^{3+}$ $(650-750 \mathrm{~nm})$ and $\mathrm{Fe}^{3+} / \mathrm{Fe}^{3+}-\mathrm{Fe}^{3+}(700 \mathrm{~nm})$. Absorption bands of $\mathrm{Fe}^{3+}-\mathrm{Fe}^{3+}$ at $377 \mathrm{~nm}$ and 450 $\mathrm{nm}$ disappeared. The absorption bands of $\mathrm{Cr}^{3+}$ became clearer after heat treatment. Centers containing ferrous iron, namely $\mathrm{Fe}^{2+}-\mathrm{Ti}^{4+}$ and $\mathrm{Fe}^{2+}-\mathrm{Fe}^{3+}$ appeared. Cherry-pink color is accounted for by a decrease in the $\mathrm{Fe}^{3+}$ content in the sample (orange tints disappeared), by a sufficient content of $\mathrm{Cr}^{3+}$ ions, which chromophore effect appears more intense after heat treatment, and by the formation of $\mathrm{Fe}^{2+}-\mathrm{Ti}^{4+}$ pairs (appearance of cherry tints in the color of the sample). 


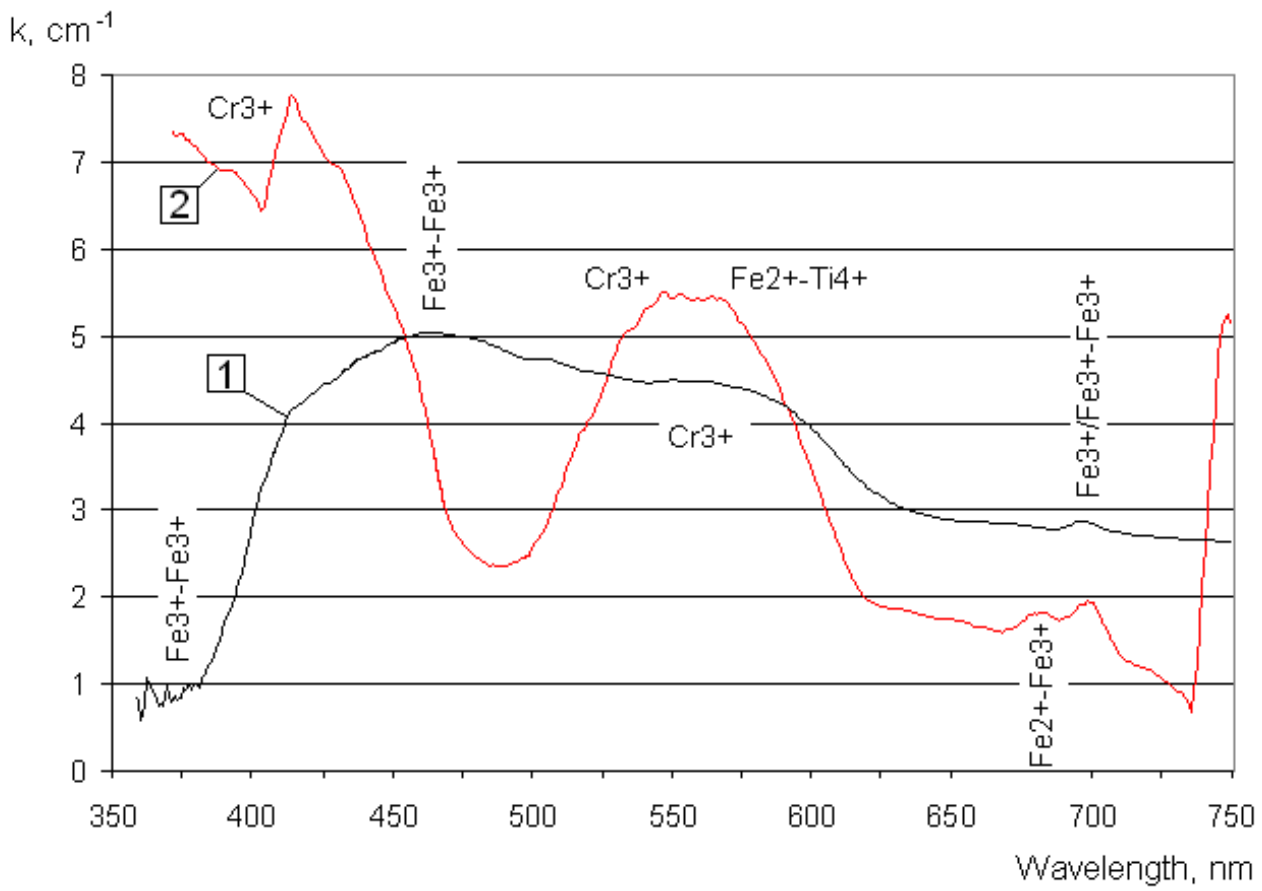

Fig. 5. The optical absorption spectrum of color sapphire before and after heat treatment: 1 - before heat treatment - rO 4/5, red-orange, 2 - after heat treatment - stpR 4/3, cherry-pink

In one experiment samples were heat treated in a reducing atmosphere at $1800^{\circ} \mathrm{C}$ with holding time $60 \mathrm{~min}$. [21]. In result not only the impurities were reduced but also the partial reducing of the corundum $\mathrm{Al}_{2} \mathrm{O}_{3}$ to metallic aluminum took place. In order to determine the nature of the formation of aluminum scanning electron microscopy was conducted. Picture of sample surface are shown in Fig. 6. The sample surface is irregularly covered with aluminum powder particles and that indicates about the diffusion character of this process. The parameters of such heat treatment are not acceptable, because they lead to "over-reduction" and damaging of the samples. So the temperature during reducing treatment should be under $1800^{\circ} \mathrm{C}$.

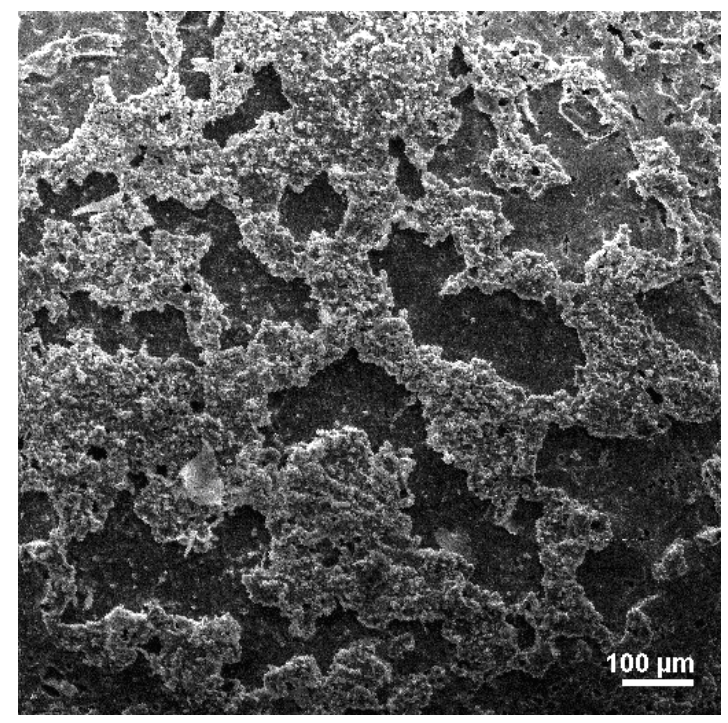

Fig. 6. Sample surface after reducing heat treatment $\left(1800^{\circ} \mathrm{C}, 60 \mathrm{~min}\right.$.) 
When heat treating color sapphires there are following main variables available for regulation: heat treatment atmosphere, working temperature and holding time at working temperature. The nature of the atmosphere, in which heat treatment is carried out, is a factor determining the direction of the whole process [21]. Thus, for sapphires containing $\mathrm{Cr}$ (III), Fe (II and III) and $\mathrm{Ti}$ (IV) impurities after oxidizing heat treatment the formation of additional amounts of $\mathrm{Fe}$ (III) will take place and that will cause the intensification of yellow tints in the color of treated sapphires. In a reducing atmosphere the amount of Fe (III) decreases, so the yellow tints become less intensive. When iron ions are reduced new chromophore centers $\mathrm{Fe}^{2+}-\mathrm{Ti}^{4+}$, which can give violet, cherry and blue tints to the treated material, are formed. The final color of the samples will be composed of the color(s) induced by heat treatment and of that one which is caused by chromophore centers of chromium ions.

The considered mechanism of color change, namely change of the valencies of chromophore impurities during the process of heat treatment, was confirmed on the basis of spectral analysis. Color changes in sapphires by heat treatment obtained in the present paper affects the entire volume of the stone considering small samples sizes and it is stable over time and irreversible under normal conditions.

\section{CONCLUSIONS}

1. The composition and structural features of the location of chromophore impurities in corundum determine the possibility of color changing of orange-red sapphires by heat treatment.

2. The effect of a reducing atmosphere and temperature on color sapphires with colors ranging from yellow-orange to red was investigated. The color of fancy sapphires changes after the heat treatment also in a weak-reducing atmosphere, but to a lesser degree, reducing is more efficient at higher temperatures. Heat treatment in a reducing atmosphere at $1800^{\circ} \mathrm{C}$ leads to complete loss of gem qualities of sapphires.

3. The following groups of color sapphires showed positive results of enhancement:

a. For the bright orange sapphires $\mathrm{O} 5 / 4$ and not dark varieties of red-orange sapphires $\mathrm{rO} 3 / 5$ at temperatures $1100-1200^{\circ} \mathrm{C}$ in reducing atmosphere obtained color is red-pink of different intensity - oR $3 / 5$ and oR $3 / 3$ respectively;

b. Heat treatment of red-pink sapphires is effective under reducing conditions at $1150^{\circ} \mathrm{C}$, the color obtained being crimson-pink, crimson-red. Crimson-red color of sapphire allows consider such stones as rubies;

c. Heat treatment at $1400^{\circ} \mathrm{C}$ in a reducing atmosphere changes color of a reddishorange $\mathrm{rO} 4 / 4$ sapphires to pink-cherry oR $6 / 2$ color and the orange-red $\mathrm{rO} 5 / 5$ sapphires become pink-red oR $6 / 4$. Under the same conditions but at $1500^{\circ} \mathrm{C}$ red-orange sapphires $\mathrm{rO} 4 / 5$ become pink-violet $\mathrm{rP} 5 / 3$ or a cherry-pink stpR $4 / 3$ depending on the heat treatment conditions.

4. This type of enhancement is economically sound because the value of treated material rises at average by 3 times when the ruby color is obtained, while costs for heat treatment itself are relatively low. The temperature range $1150-1400^{\circ} \mathrm{C}$ in a reducing atmosphere is optimal for the enhancement of orange-red sapphires since the reducing of ferric impurities goes most actively under these conditions. The higher working temperatures of heat treatment lead to an increase in the concentration of forming chromophore centers 
$\mathrm{Fe}^{2+}-\mathrm{Ti}^{4+}$. Visible effect of chromophore pairs $\mathrm{Fe}^{2+}-\mathrm{Ti}^{4+}$, giving a bluish tint to stones, appears in samples after heat treatment at temperatures above $1450^{\circ} \mathrm{C}$ in a reducing atmosphere.

5. Thus, the method was developed that allows to improve the color of orange-red sapphires and achieve ruby color in them. This method can be used as well for other color sapphires. The authors are working on the heat treatment of sapphires of other color groups to improve their color (at this stage the principles of heat treatment for yellow and green sapphires are established), and also experimenting about lightening technology for dark blue sapphires. Application of this type of enhancement is perspective for corundum containing chromophore impurities of variable valencies for improving their quality characteristics.

\section{REFERENCES}

1. Winotai P., Limsuwan P., Tang I.M., Limsuwan S.: Quality enhancement of Vietnamese ruby by heat treatments. Australian Gemmologist, 22 (2004), 72-77.

2. Бахтин А.И., Горобец Б.С.: Оптическая спектроскопия минералов и руд и ее применение в геологоразведочных работах. Изд-во Казан. ун-та, Казань, 1992.

3. Платонов А.Н., Таран М.Н., Балицкий В.С.: Природа окраски самоцветов. Недра, Москва, 1984.

4. Свиридов Д.Т., Свиридова Р.К., Смирнов Ю.Ф.: Оптические спектры ионов переходных металлов в кристаллах. Наука, Москва, 1976.

5. Lehmann G., Harder H.: Optical spectra of di- and trivalent iron in corundum. The American Mineralogist, 55 (1970), 98-105.

6. Nikolskaya L. V., Terekhova V. M., Samoilovich M. I.: On the origin of natural sapphire color. Physics and Chemistry of Minerals, 3 (1978), 213-224.

7. Burns R.G.: Intervalence Transitions in Mixed Valence Minerals of Iron and Titanium. Annual Review of Earth and Planetary Sciences, 9 (1981), 345-383.

8. Fontana I., Le Donne A., Palanza V., Binetti S., Spinolo G.: Optical spectroscopy study of type 1 natural and synthetic sapphires. Journal of Physics: Condensed Matter, 20 (2008), 125228125232.

9. Eigenmann K., Gunthard Hs. H.: Valence states, redox reactions and biparticle formation of Fe and Ti doped sapphire. Chemical Physics Letters, 13 (1972), 58-61.

10. Townsend M.G.: Visible charge transfer band in blue sapphire. Solid State Communications, 6 (1968), 81-83.

11. Maxwell M.: The processing \& heat treatment of Subera (Queensland) sapphire rough. Australian Gemmologist, 21 (2002), 279-286.

12. Emmett J.L., Douthit T.R.: Heat Treating the Sapphires of Rock Creek, Montana. Gems\&Gemology, 29 (1993), 250-272.

13. Nassau K.: Gemstone Enhancement. Butterworth-Heinemann, Oxford, 1994.

14. Здорик Т.Б., Фельдман Л.Г.: Минералы и горные породы. Т. 1. (Ювелирные камни и драгоценные металлы). Энциклопедия природы России. АBF, Москва, 1998. 
15. Peretti A., Guenther D.: The color enhancement of fancy sapphires with a new heat-treatment technique (Part A): Inducing color zoning by internal migration and formation of color centers. Contributions to Gemology, 11 (2002), 1-48.

16. Emmett J.L., Scarratt K., McClure S.F. et al.: Beryllium diffusion of ruby and sapphire. Gems\&Gemology, 39 (2003), 84-135.

17. Bgasheva T.V., Akhmetshin E.A., Zharikov E.V.: Enhancement of colour characteristics of fancy sapphires by heat treatment in reducing condition. Proceedings of 30th International Gemmological Conference, Moscow, 2007, 23-24.

18. Марфунин А.С.: Введение в физику минералов. Недра, Москва, 1974.

19. Nassau K.: Irradiation-induced colors in gemstones. Gems\&Gemology, 16 (1980), 343-355.

20. Ахметшин Э.А., Бгашева Т.В.: Влияние гамма- и электронного облучения на окраску цветных сапфиров. Материалы V Межвузовской научной конференции студентов, аспирантов и молодых ученых «Молодые - наукам о Земле», РГГРУ, Москва, 2010, 121.

21. Ахметшин Э.А., Бгашева Т.В.: Изучение влияния времени воздействия рабочих температур на облагораживание цветных сапфиров при термообработке. Горный информационно-аналитический бюллетень (научно-технический журнал), 1 (2009), 274280.

22. Неуструев В.Б.: Исследование спектрально-люминесцентных свойств рубина как активной среды оптического квантового генератора. Центры люминесценции в кристаллах. Труды ФИАН, 796 (1974), 3-38.

23. McClure D.S.: Optical Spectra of Transition-Metal Ions in Corundum. Journal of Chemical Physics, 36 (1962), 2757-2779.

24. Achiwawanich S., James B.D., Liesegang J.: XPS and ToF-SIMS analysis of natural rubies and sapphires heat-treated in a reducing $\left(5 \mathrm{~mol} \% \mathrm{H}_{2} / \mathrm{Ar}\right)$ atmosphere. Applied Surface Science, 255 (2008), 2388-2399. 